\title{
UKRAINIAN POST-IMPERIAL SCIENCE ABOUT LITERATURE:KEY FACTORS OF FORMATION
}

\section{Ivanyshyn P. V.}

\section{INTRODUCTION}

The purpose of this studio is to give a generalized author's vision of the main factors of formation of the newest Ukrainian science about literature, which is in no way claimed to be exhaustive and definitive. In our view, both creation, perception, and interpretation of this image are impossible without Lina Kostenko's observation, which accurately defines the outlines of the latest «concrete-hermeneutic situation» (G.-G.Gadamer): «We are opening Ukraine in Ukraine, and this does not threaten anyone with the loss of territories or spiritual values. It just demands a revision of the usual scheme and rearrangement of incorrectly placed mirrors.

Ukrainians are a nation that has been displaced for centuries by physical destruction, spiritual expropriation, and genetic mutations, goaldirected mixing of peoples within its territory, because of this amnesia of historical memory and a qualitative loss of the national genotype itself was happened. Her image has been distorted for centuries... It is a great miracle that this nation is still present, it could have been leveled and disappeared a long time ago. In fact, it is a rare nation, lonely on its own land in its great society, and even lonelier in the universe of humanity. Phantom of Europe, which only at the end of the century began to acquire real features for the world. It is waiting for its philosophers, historians, sociologists, geneticists, writers, artists. Neurasthenics are asked not to worry».

The qualitative changes in the Ukrainian humanitarian space, which have drawn since the mid-1980s (during the so-called «reconstruction» in the USSR), have received a new impulse with the disintegration of the Soviet empire and Ukraine's independence in 1991. The same changes directly affected Ukrainian literature and the complex of literary disciplines. Colonial cultural and historical circumstances of the formation of scientific existence (totalitarianism of thinking of the RussianCommunist model, censorship of the Communist Party, omnipotence of repressive bodies, the only-correctness of the ideology of the CPSU, etc.) have disappeared into the past. Instead, the post-colonial realities of the young state, with their obvious advantages and disadvantages, began to form epistemological reality. 


\section{External factors of formation of the postcolonial literary studies}

In the post-imperial period the development of the Ukrainian science about literature was determined by two groups of factors: external, extrascientific, which influenced the creation of new circumstances for the existence of science, and internal, constituting from the inside the ways of modern Ukrainian philology. The main external factors were: sociopolitical, ideological and ideological, cultural, philosophical, economic, socio-psychological and religious. Although it is worth noting that, in general, extra-scientific factors began to play a smaller role in epistemological development than it was in the Soviet period.

The defining socio-political reality was gaining independence by Ukraine, which was associated with the appearance of opportunities to build a truly independent nation state with a well-developed infrastructure and the realization of a versatile national revival of colonized by centuries Ukrainian people. The stateless nation was given the chance to finally become a State nation. However, unfortunately, the national-liberation revolution of the late 1980 s did not come to a logical political end. The post-colonial «state of Ukraine» never became a full-fledged state of the Ukrainians, no the ideology of state-building was created and, accordingly, the strategy of versatile national revival, Ukrainian culture and language did not receive due support from political leadership.

According to experts, the post-colonial state has more and more acquired features of the neo-colony of Russia and Western superpowers, covered up by pseudo-democratic institutions. The two large-scale national uprisings (the Maydans of 2004 and 2013-2014) and the RussianUkrainian war, which began with the Moscow's annexation of the Crimea and the formation of pro-Kremlin puppet regimes in Eastern Ukrainian lands in 2014, were the political confirmations of the neo-colonial status quo. Vitaliy Donchyk, comprehending the cultural and historical situation of the 1990s, emphasized that our people, «having been got freedom, is still threatened», that «our language, culture, history, spirituality ... were found in a Horde siege», and this situation of «internal occupation» (V. Ivanyshyn's term) summarized as follows: «They want one from us, but essentially everything: that we would not be masters on our land, we would not be conscious of ourselves a nation with all its defining signs, priorities - like all nations in Europe ${ }^{1}$.

${ }^{1}$ Дончик В.Г. “А ми ще є” (“Берестечко” Ліни Костенко). Дончик В.Г. 3 потоку літ і літпотоку. К. ВД “Стилос”. 2003. С. 402-403. 
The development of Ukrainian culture, including science, has become mainly an affair of individual institutions, enthusiasts-ascetics and civic organizations. And, according to Ivan Fizer, it should be, above all, a large-scale state affair: «...this is about creating such a dianoya and such a pandeya by the state, that is, such an intellectual paradigm and such a system of education that would take into account maximum of intellectual, ethno-psychological, moral and utilitarian aspects of the Ukrainian nation. In such a context of humanitarian policy, and only in this, Ukrainian philology will have the opportunity to grow and function» ${ }^{2}$.

Postcolonial reality was marked by the active confrontation of various ideologies - social worldviews. The former key confrontation of communist / anti-communist has been changed by a confrontation between existentially historical, national-centric systems of ideas and their imperial and cosmopolitan opponents. Among the latest, the revanchist (communist, socialist), Muscovite (neo-Eurasian) and Eurocentric (neo-liberalism, multiculturalism, globalism, feminism, gender) doctrines played a significant role. It is typical that these universalist ideologies produced various cultural imperialisms (E. Smith, E. Said), appealing to a variety of «universal», «global», supranational values («general-human», «internationalist», «common Slavic», «Eurasian», «class», etc.) intended to devalue the organic and cultural values, in order to ensuring political, economic and cultural domination over different countries and peoples. All these ideological confrontations between supporters and opponents of national value systems were also actively present in Ukrainian humanities, often defining the nature as if purely scientific discussions and polemics ${ }^{3}$.

The general-cultural factor has manifested itself in several aspects. First of all, the influence of the Russian-Soviet colonial paradigm has significantly decreased, however, not everywhere and not always (although many Soviet rituals, myths and symbols remain in the information space of the country). On the other hand, the presence of the Ukrainian cultural tradition has intensified. The penetration of Western mass-cultural

${ }^{2}$ Фізер І. Зустрічі чи зіткнення української філології із західними методологічними стратегіями. Слово і час. 2006. №4. С. 8.

${ }^{3}$ Бойчук Б. Про літературну історіософію та бешкетування в літературі. Критика. 2002. Ч. 6. С. 32; Дончик В. Так хто ж реанімує ідеологізацію? Літературна Україна. 2007. 14 червня; Іванишин П. Захист після захисту, або Новітній тип політичної цензури. Літературна Україна. 2007. 21 червня; Клочек Г. Проблема Григорія Грабовича: момент істини. Дзеркало тижня. 2003. 1 листопада; Фізер I. Зустрічі чи зіткнення української філології із західними методологічними стратегіями. Слово і час. 2006. №4. С. 5-10; Хоменко О. Любитипо-гарвардськи: типологія процесу. Хоменко О. Есеї республіканської осени. Тернопіль. Джура. 2011. С. 100-105. 
stereotypes and the latest Russian pop culture (through the radio, television, newspapers, books, Internet, etc.) has also become appreciable. This cultural-semiotic chaos, unverified by a conscious and clear state policy in the spiritual sphere, has become deeper in common-world tendencies. For example, the «catastrophic collapse of cultural values» (J. Ryus) in Western societies, which became expressive after the Second World War. Cultural spheres as a system of national-spiritual values (M. Weber, P. Ricker) have been increasingly suffered invasion and devaluation by anti-cultural ersatz. Mentioned tendencies, unfortunately, directly concerned the latest Ukrainian literary criticism as an organic branch of any national culture. From here, the key task of the Ukrainian post-Soviet society, formulated, for example, by Mykola Zhulynskiy in the context of awareness of the importance of «national factor, or more widely, nationalism» by the significant part of Ukrainian intelligentsia, became expressive ${ }^{4}$.

The philosophical factor is most noticeably manifested at the deepest, theoretical level of scientific consciousness, and also had a worldwide character. It is about an accelerated development in the age of Modern (from the 15th century) of devastating, calculating, shopkeeper («calculated», according to M. Heidegger) thinking, the sources of which are found in antiquity. At the same time there was a decline of the existential and historical thinking («comprehending considerations»), the shepherding thinking and the affirmation of nihilistic, technocratic, antiexistent thinking, called not to protect, but to rule over being, to exploit and, as a result, to destroy it. Many scientists in Ukraine and in the world have become hostages of namely nihilistic or partially nihilistic (eclectic) types of philosophizing. At the same time, the aspiration to discover the «nihilistic metaphysics of post-structuralism» (I. Ilyin) and to critically comprehend the following tendencies were noticeable: «It is clear understandable aspiration to join the latest philosophical and aesthetic ideas and «to be on par with Europe» acquires too straight-linear forms, turns of an uncontrollable desire absolutely everything «transfer» to us and free or non-free neglecting of the peculiarities of national development» ${ }^{5}$.

The economic factor was a natural consequence of two economic tendencies. At the local level, it is a systemic crisis (especially deep in the 1990s) in the Ukrainian economy that has caused miserable, residual

4 Жулинський М. Національна культура за умов формування нової суспільної солідарності в Україні. Сучасність. 1997. №1. С. 68.

${ }^{5}$ Дончик В. Про історію літератури, якої досі не було. Слово і час. - 2002. - № 4. C. 7. 
financing of the cultural sphere, and in the social sphere has generated a shameful stratification on a small stratum of oligarchs-fast-enriched (mostly indifferent to the problems of the Ukrainian national-spiritual development) and the absolute majority of society that was permanently below the poverty line. At the global level, these are frequent global crises that have deprived entire countries and nations of economic independence for the benefit of foreign political elites or transnational corporations and banks. In such circumstances, adequate material ensuring of Ukrainian education and science became an impracticable dream. From here, the absence of a large number of educational and scientific publications and institutions, frequent emigration abroad or refusal from the active scientific activity of leading scientists, and an unfortunate dependence on foreign grant funds, which were often allocated to questionable or controversial, from the point of view of the immanent scientific interests, projects, were noticeable.

The socio-psychological factor significantly influenced the formation of creators and recipients of literary and literary studies production. Particularly notable was the phenomenon of marginalization as a pathology of the spirit. We are talking about the appearance and notable activity since the nineteenth century of national marginals, spiritually alienated individuals. These are «non-rooted» (by S. Weil), denationalized, torn between several cultures, deprived of a whole national identity people who often aspired «endless self-affirmation»(D. Bell). In an independent Ukraine, new anthropological varieties were added to the ancient types of marginals -with the consciousness of the «Soviet people» (the so-called «scoops»): a large number of westernized, westernized (West-oriented) and neo-Russophile individuals (from the 2014 outlined as «separatisti» and «wadding-men») in the intelligentsia environment.

To some extent, some common European tendencies have manifested themselves. Destruction by Europeans in the twentieth century of their own national archetypes, sacred symbols caused, according to Karl-Gustave Jung, to a mental devastation, to search of false ways of rescue: «We allowed falling a home built by our parents, but now try to get into the eastern palaces about which our ancestors had no idea. (...)... the vacuum is filled with the most absurd political and social ideas, the different feature of which is spiritual devastation». Not by chance, perhaps, that the same 
author noted at this time an increase in the number of patients sick on neuroses, schizophrenia, paranoia ${ }^{6}$.

This internal socio-psychological situation is complicated by global tendencies. According to experts, modern Euro-Atlantic civilization (and not only it) has been imbued with the ideologemes of liberal «postmodern democracy» and «global capitalism». It is governed and governs by a layer of inefficient managers - shopkeepers and consumers (spiritual «Vaishya»). According to modern researchers, «Vaishya culture tendencies, which are based on the cult of consumption, lead to a consistent removal of moral taboos and to go out beyond all possible cultural frames. The decline of the major social institutions (family, civil society, ideology, classical culture) witnesses that the upper «ozone» layer of the social organization is being quickly destroyed today ${ }^{7}$. In the field of social, including scientific, communication the phenomenon of hypertextuality (excessively of sign systems) has been expanding, which has led to lack of perception, understanding, reflection, practicality (applying). Moreover, many works of art and literary studies have become more and more imitations, «forgeries» (R.-M.Rilke) or «simulacra» (J. Baudrillard) in the fields, accordingly, of literature or science.

An important spiritual and religious factor was also important in the 1990s. The artificial spreading of atheism by the imperial communist power or controlled by the Soviet special forces Moscow Orthodoxy changed in the post-colonial period with a perceptible tendency of restoring organic religious identity and conversion of the Ukrainians to traditional Orthodox and Greek Catholic churches. All this has caused to a certain restoration of spiritual and religious literary creative work and based on the Christian (philosophical and theological) tradition of humanitarian reflection. The interest in biblical studies, theology, religious philosophy, personalism, theoretical foundations of Christian exegetics, etc. was revived. Interdisciplinary interpretations of «Christianity as the foundational basis of literary creative work» have become systematic ${ }^{8}$.

However, these positive processes had to co-exist and conflict with the latest pan-European tendency caused by ideological domination within the Euro-Atlantic community of liberal secularism and atheism. This was not

6 Левчук Л. Західноєвропейська естетика XX століття. Навчальний посібник. К. Либідь. 1997. 224 с.

7 Розумний М.М. Доктрина дії: Соціально-філософський конспект. Х. Майдан. 2009. С. 97.

8 Хороб С.І. На літературних теренах. Дослідження, статті, рецензії. ІваноФранківськ. ПНУ ім. В.Стефаника. 2006. С. 239. 
about a random or temporary phenomenon, but a systematic, «long process of secularization and dehumanization» (D. Fockem), which led to a peculiar fashion of atheism in the surrounding of Western intellectuals or, accordingly, part of the westernized Ukrainian scientists (from here, for example, defending of religious relativism, cynicism and skepticism, the principles of the sexual revolution and gender ideology, the promotion of homosexuality, or other sexual perversions, as if «democratic» gender norm, etc.).

\section{Intra-scientific factors of the newest literary process}

However, no matter how significant were the external factors of the literary process, influencing the collective consciousness and the conditions of being of each humanitarian, intro-scientific (internal) factors: methodological, aesthetic and literary began to play a major role in the time of independence - with the disappearance of total Communist Party control.

The most significant of all internal factors - methodological - factor has manifested itself as a consequence of the historical change of epistemological paradigms. In Soviet times, methodological monism prevailed in social thinking, especially in the humanities, in particular, in literary studies, as well as in artistic creative work: there was one and only «correct» Marxist-Leninist methodology and the only analytical and at the same time the creative method of socialist realism. Everything else was considered bourgeois, false, or criminal (or at least secondary), and any, even involuntary, attempts to go out this «methodology» and this «method» were severely punished (in some periods of colonial history even by imprisonment or physical destruction).

With the independence of Ukraine, another, contrary to methodological monism, the epistemological principle - methodological pluralism, was established. There were created such conditions when each scientist or artist was free to determine, at his or her own discretion, from which methodological positions to analyze his or her subject of study, which of the numerous methods to use. This widened possibilities and raised quality of both cognitive and creative activities, caused appearance of large number of interesting and productive scientific explorations.

However, it should be taken into account that sometimes the work lost logical unity and gracefulness, and sometimes the main thing - the awareness in the name of which it was performed. The creator and the perceptor of scientific products often found himself in a difficult situation, because his thinking was often determined by the lack of established and consistent methodological position, which made it impossible for effective 
scientific communication: speech and consciousness of analysts and recipients became «a set of rather eclectic approaches, slogans, conclusions that often contradicted one another, if not within the same utterance, then within one speech» ${ }^{9}$. Thus, in the context of methodological pluralism, each time some organizing, system-forming factor, some methodological dominant was needed. Unfortunately, this cognitive regularity has been taken into account (and is still taken into account) by not all researchers, which inevitably reduced the quality and argumentativeness of analytical procedures.

Another danger of methodological pluralism has been the use by some researchers of contradictory, from a scientific point of view, and heteronomous (foreign) national scientific tradition approaches. (At the same time, some of the used methods were directly reminded about new political directives that forced the researcher not to study, but to falsify, to «over-interpret» (U. Eko) artistic reality in the interests of the colonialist political doctrine; which allowed Sergiy Kvit, for example, to describe postmodernism as a «fetishisation of liberalism» in the spirit of the previous definitions of Richard Rorty or Brian Shaw, who wrote about «postmodern bourgeois liberalism».) That is, it was about the use of a primarily Western scientific experience without any critical comprehension and transformation in accordance with the concepts and experience of the national scientific paradigm.

In the article in 1993, Solomiya Pavlychko was one of the first who diagnose the danger of such a process. The Ukrainian researcher offered in response to the crisis literary phenomena - «theory or philosophization of literary studies» and at the same time warned against inorganic ways of its solving: "The topic of today's discussion is just as dangerous, because it easily pushes in recent times on a popular way of comprehensive, unprecedented distribution of recipes ... At the forefront of this movement are some respected professors of Ukrainian origin and American citizenship, in every second sentence of their articles on this subject, using the sacrament word «necessary» ${ }^{10}$. In the 1990 s, many humanitarian authorities began to warn against postmodern «desacralization» (L. Kostenko), «neoBolshevism» (I. Denysiuk), «democratic nihilism» (I. Dziuba), or «political anti-Ukrainian literary criticism» (Val. Shevchuk).

9 Розумний М.М. Доктрина дії: Соціально-філософський конспект. Х. Майдан. 2009. C. 107.

i0 Павличко С. Методологічна ситуація в сучасному українському літературознавстві. Павличко С. Теорія літератури. Передм. Марії Зубрицької. К. Видво Соломії Павличко «Основи». 2002. С. 488, 483. 
In fact, at that time, another, national-centric position was formed, based on national-philosophical (national-existential) hermeneutics: productive philosophizing of the science of literature in the spirit of applying methodological pluralism can be only then, when, by generalization of Gregory Syvokin, the researcher will not forget about «historical and national determining of literary-theoretical knowledge» ${ }^{11}$. According to these reflections, S. Andrusiv, O. Bagan, M. Bondar, O. Vertiy, Ya. Garasym, R. Golod, I. Denysiuk, I. Dziuba, D.Drozdovskiy, V. Donchyk, M. Zhulynskiy, N. Zborovska, V. Ivanyshyn, S. Kvit, G. Klochek, V. Morenets, L. Moroz, M. Nayenko, A. Pogribniy, T. Salyga, L. Senyk, L. Skupeiko, I. Fizer, O. Khomenko, S. Khorob, N. Shumylo and others literary critics have spoken and created, however, these warnings have not always been heard. From here, it became possible to generalize postcolonial theoretical experience as a «commotion on the methodological field» (I. Dziuba), «spreading of methodologies» (M. Nayenko), or «collision of Ukrainian philology with Western methodological strategies» (I. Fizer).

It is natural that the production of a part of Ukrainian post-imperial literary critics (V.Ageeva, G.Grabovych, T.Gundorova, etc.) formed a somewhat indifferent to the real scientific needs, cultural situation and literary reality, meta-discourse, about which in his time GomiBgabga wrote in reference to the Western experience: «The demands of the land, the survival of the race, the cultural revival - all demand the understanding and answers to the very concepts and structures that academics of poststructuralism elucidate in language games, and few of them know about the political struggle of the real people outside those discursive boundaries ${ }^{12}{ }^{2}$.

The changing of paradigms of literary thinking also happened under the influence of aesthetic factor. Here, the aesthetic variety replaced the doctrine of Marxist-Leninist aesthetics that prevailed in Soviet times. It was about the variety of theories of interpretation of the beautiful, the concepts of the beautiful and the arts and artistic practices. Numerous diaspora editions (original and reprinted) that became available in continental Ukraine (works by L. Biletskiy, I. Ohiyenko, D. Dontsov, Yu. Lypa, E. Malaniuk, Yu. Klen, M. Shlemkevych, U. Samchuk, E. Onatskiy, L. Luttsiv, Yu. Sherekh, Y. Lavrinenko, Yu. Boyko, I. Mirchuk, V. Yaniv, I. Kachurovskiy, I. Koshelivets, B. Kravtsiv,

11 Сивокінь Г.М. У вимірах сприймання. Теоретичні проблеми художньої літератури, іiї історії та функцій. К. Фенікс. 2006. С. 34.

12 Слемон С., Тіффін Г. Постколоніальна критика. Антологія світової літературнокритичної думки ХХ ст. За ред. М.Зубрицької. Львів. Літопис. 1996. С. 537. 
V. Derzhavyn, Yu. Lutskiy, I. Fizer, G. Grabovych, R. Rachmanniy, T. Skrypka, etc.) have promoted to this.

These discourses, on the one hand, promoted to the emancipation of artistic thought and creative work, and, on the other, sometimes paradoxically promoted to the latest restrictions. True, as the researchers observed, these restrictions and even censorship appeared already in the coordinates of not communist, but liberal nihilism, linked first of all with the well-known tendency to devaluation or «dehumanization of art» (H. Ortega-and-Gasset) - the guidelines of cosmopolitan («decomposing» after D.Dontsov) modernism, avant-gardism, and postmodernism. Clearly nihilistic elements - imperialism, atheism, materialism, cosmopolitanism, feminism, humanism, anti-traditionalism, sexual revolution, multiculturalism, genderism, etc. - have caused, according to some authors, to the degeneration and tiredness of European cultures. It is bluntly manifested in aesthetics and art.

The post-colonial aesthetic consciousness of Ukrainians in the 1990s fully met with what the Western cultures were the largest collided in the period of World War II. John Fowls wrote in this regard about «the tyranny of self-expression» and outlined other aspects of post-war «black art»: «One of the most striking features of our age has been the everywhere use of poles of violence, cruelty, evil, danger, fuss, ambiguity, iconoclasm, anarchy in the popular and intellectual amusements $\gg{ }^{13}$. In this creative work, «registers, attributes and aspects of the inhuman seize a person and his nearest world, his nature and all his ideas» (G. Zedlmayer).

Traditional aesthetic and hermeneutical ideas, according to esthete Vladyslav Tatarkevych's, impel to consider art as a part of culture that arises through the artist's skill, forms a «separate continent in the world» and exists exclusively in the works of art. Instead, avant-garde-postmodern theories have tried to confirm another position in which art arises as an «enemy of culture» (J. Diubiuffe), arises as something opposite to skill that is why «everything is art» (G. Arp) or «a work of art becomes everything that can gather attention on itself» (M. Porembskiy), becomes identical to any, even everyday, activity. From here the idea about the loader as an artist (G. Rosenberg), the appearance of the so-called «concrete poetry», «plastic sound», performances, etc. Finally, art is detached from works of art, it arises as an abstract «creative work» - so, let's say, it is enough the existence of an intention, not a work for R. Morris: «There are no more works of art, there are only artistic

\footnotetext{
${ }^{13}$ Фаулз Дж. Арістос. Вінниця. Тезис. 2003. С. 283.
} 
situations» $(\mathrm{A} . \mathrm{Mol})^{14}$. The coexistence and conflict of art and anti-art theories and practices became an attribute feature of Ukrainian postcolonial culture.

Aesthetic relativism, perceived by a number of Ukrainian literary critics, has generated two major tendencies. Part of the researchers, as if fearing relapses of communist «ideologization,» refused to admit the ideological, intentional, spiritual-forming component of art, taking down its leading function to a very differently interpreted, and thus fundamentally relative, aestheticism. In this way, the vision of the essence of art as a spiritually-creative, socially-cultural, ultimately ontological phenomenon, and literature as a «source of a complete historical herebeing of the people, was essentially narrowed» (M. Heidegger). The other part - in general, had doubts about the existence of any criteria of artistic ${ }^{15}$. Such ahistorical and anti-hermeneutic, postmodern position forced these researchers to elevate «their subjective spontaneity to the rank of the only equivalent criterion of cognition», impelled, following Ivan Fizer's observation, to a radical gap with the past, which marked the «intensified decentralization of the cultural field, relativizing of all values, erasing the boundaries between intellectual erudition and thought, science and supposition, finally, between elitist and mass cultures» ${ }^{16}$.

All this painful was reflected first of all on theoretical reflection and on the quality of literary criticism, impelled to the creation of a rather aggressive, «Ukrainian-phobic academic international»(S. Kvit), to the unmotivated glorification of little-artistic or anti-aesthetic phenomena, and, on the contrary, to the subjective objection or reticence of phenomena of truly artistic value. Those researchers who nevertheless confirmed and creatively developed classical hermeneutic and aesthetic ideas about art, the opponents were often interpreted as «fascists», «nation-realists», or «Old World nationalists» in the heat of polemic, resorting to not entirely scientific terminology.

The literary factor was directly dependent on the aesthetic factor. In the period of independence, the very object of the literary studies and idea about it has significantly changed. At the base of the social-realist canon

14 Татаркевич В. Історія шести понять: Мистецтво. Прекрасне. Форма. Творчість. Відтворництво. Естетичне переживання. Пер. $з$ пол. В.Корнієнка. К. Юніверс. 2001. С. 45-47.

15 Іванишин П. Критерії художності: актуалізація базового поняття. Українське літературознавство. 2010. Вип. 69. С. 70-75.

16 Фізер I.М. Американське літературознавство. Іст.-критич. Нарис. К. Вид. дім «Києво-Могилянська академія». 2006. С. 76. 
was the idea of literature as a party-class phenomenon, the "wheel and screw of the proletarian affair» (V. Lenin), which defined the following triad: literature - national in form, socialist in content, international in spirit. From here are the Marxist-Leninist restrictions of the creative work of Soviet writers, the withdrawing of a number of periods and hundreds of authors from the history of literature, a significant aberration of classics, dialogue with world literature through mediation of Russian literature, etc. These include the imposition of the principles of pseudo-historicism to the art of words («the connection of literature with social reality and class struggle»), «Soviet patriotism», humanism, atheism, irreconcilability with the manifestations of «bourgeois nationalism» and, as Alexander Biletskiy wrote in 1948, the struggle against «the creeping in front of the West» ${ }^{17}$. Although, of course, there were whole creative experiences and individual works that consciously went out beyond the social realism and formed the literature of resistance. In the post-colonial period, literature was able to be what it should be - the art of words, an important element of national culture, an artistic fact and a factor of human-creation, nation-creation and spiritual and aesthetic transmission. As hermeneutics long since witnesses: «Literature ... plays the role of the function of spiritual preservation and tradition, and that's why it brings a hidden history into everything modern ${ }^{18}$.

Many writers have seized this opportunity, creating the newest Ukrainian literature, by innovator way mastering and developing national and other-cultural experiences. However, the other part was to a greater or lesser degree oriented towards the tradition of Western aesthetic nihilism, with its anti-cultural and anti-artistic dominants. Literature has again been politicized, however, not so clearly as in the Soviet period, and this time from the position of another ideological doctrine - in a radical-demoliberal (with non-Marxist admixtures) spirit. Literature, if admits as an artistic phenomenon, then in a rather aberrant, extra-cultural look: again national in form only, liberal in content and cosmopolitan in spirit (sense).

The appearance and activation of numerous literary groups that cultivated avant-garde and postmodern «writing» caused constant discussions and polemics in the surrounding first of all of the writers themselves, in which specialist literary critics were gradually involved. Some referred literature that cultivates lack of spirituality, nihilism,

\footnotetext{
${ }^{17}$ Скупейко Л., Дончик В. “Слово і час”: сторінки українського літературознавства. Слово і час. 2002. №8. С. 8-10.

18 Гадамер Г.-Г. Істина і метод. Пер. 3 нім. К. Юніверс. 2000. Т. І. Герменевтика І. Основи філософської герменевтики. С. 146.
} 
devastation, vulgarity, neo-cynicism to the phenomena of «anti-aesthetics», «anti-literature», «anti-art» (Val. Shevchuk), or, as Volodymyr Panchenko speaks, «genital literature,» others, however, believed that it was «normal» or «only possible» literature.

\section{CONCLUSIONS}

So, in the post-imperial period the development of the Ukrainian science about literature was determined by two groups of factors: external, extra-scientific, which influenced the creation of new circumstances for the existence of science, and internal, constituting from the inside the ways of modern Ukrainian philology. The main external factors were: sociopolitical, ideological and ideological, cultural, philosophical, economic, socio-psychological and religious. However, the main role in the formation of the newest literary process was played by intra-scientific (internal) factors: methodological, aesthetic and literary.

These mentioned factors have inevitably influenced on the formation of post-imperial scientific consciousness. This was manifested in the formation of different (often eclectic, polar) ideas about the art of words, in re-reading (often selective) of history of Ukrainian literature, in uneven deeper or superficial - understanding of «white spots», in creating their own (often very subjective) literary canons, in not always motivated detracting or exaggeration of the role and importance of separate periods, schools, personalities, etc. Obviously, the outlined factors can hardly be called the only ones that determined the essence of the post-colonial literary process. However, without taking them into account, understanding of the post-imperial science of literature will, in our opinion, be deprived of stereoscopicity and depth.

\section{SUMMARY}

The article attempts to give a generalized author's vision of the main factors of the formation of modern Ukrainian science about literature, which in no way claims to be exhaustive and definitive. The author attributes socio-political, ideological, generally-cultural, philosophical, economic, spiritual and religious, methodological, aesthetic, literary to the main factors. The author argues that in the post-imperial period the development of the Ukrainian science about literature was determined by two groups of factors: external, extra-scientific, which influenced the creation of new circumstances for the existence of science, and internal, constituting from the inside the ways of modern Ukrainian philology. The main external factors were: socio-political, ideological and ideological, cultural, philosophical, economic, socio-psychological and religious. 
However, the main role in the formation of the newest literary process was played by intra-scientific (internal) factors: methodological, aesthetic and literary. These mentioned factors have inevitably influenced on the formation of post-imperial scientific consciousness. This was manifested in the formation of different (often eclectic, polar) ideas about the art of words, in re-reading (often selective) of history of Ukrainian literature, in uneven - deeper or superficial - understanding of «white spots», in creating their own (often very subjective) literary canons, in not always motivated detracting or exaggeration of the role and importance of separate periods, schools, personalities, etc.

\section{REFERENCES}

1. Андрусів С.М. Модус національної ідентичності: Львівський текст 30-х років XX ст. Львів. Львівський національний університет імені Івана Франка. 2000. Тернопіль. Джура. 2000. 340 с.

2. Бойчук Б. Про літературну історіософію та бешкетування в літературі. Критика. 2002. Ч. 6. С. 32.

3. Бондар М. Українська література класичного періоду: рух крізь категорію художності. Нова історія украӥнської літератури (теоретико-методологічні аспекти). Зб. К. Фенікс. 2005. С. 220-234.

4. Боротьба нового і старого чи витіснення національного? (Постмодернізм - український варіант сьогодні й завтра) [Учасники полілогу В. Дончик, Д. Дроздовський, П. Іванишин]. Слово $i$ час. 2008. № 6. С. 16-35.

5. Гадамер Г.-Г. Істина і метод. Пер. 3 нім. К. Юніверс. 2000. Т. І. Герменевтика I. Основи філософської герменевтики. 464 с.

6. Денисюк I. Кілька міркувань щодо концепції нової української літератури (із приводу сучасного підручника). Нова історія української літератури (теоретико-методологічні аспекти). 3б. К. Фенікс. 2005. С. 117-130.

7. Дзюба I. Метод - це насамперед розуміння. Дзюба I.M. 3 криниці літ: У 3 m. К. Вид. дім «Києво-Могилянська академія». 2006. T. 2. C. $677-687$.

8. Дончик В. Про історію літератури, якої досі не було. Слово $i$ час. - 2002. - № 4. - С. 6-19.

9. Дончик В. Так хто ж реанімує ідеологізацію? Літературна Україна. 2007. 14 червня.

10. Дончик В.Г. «А ми ще є» («Берестечко» Ліни Костенко). Дончик В.Г. 3 потоку літ $i$ літпотоку. К. ВД «Стилос». 2003. C. $400-408$. 
11. Жулинський М. Національна культура за умов формування нової суспільної солідарності в Україні. Сучасність. 1997. № 1. C. 65-70.

12. Зборовська Н. Сучасне українське літературознавство: локальний конфлікт в Інституті літератури чи порубіжна наукова дискусія? Слово і час. 2007. № 7. С. 3-11.

13. Іванишин В.П. Нариси 3 теорії літератури: навч. посіб. [упоряд. тексту П.В. Іванишина]. К. ВЦ «Академія». 2010. 256 с.

14. Іванишин П. Захист після захисту, або Новітній тип політичної цензури. Літературна Україна. 2007. 21 червня.

15. Іванишин П. Критерії художності: актуалізація базового поняття. Украӥнське літературознавство. 2010. Вип. 69. С. 70-75.

16. Іванишин П. Літературознавство як кітч? [рец. на кн.] Гундорова Т. Кітч і Література. Травестії. К. Факт. 2008. 284 с. Слово $i$ час. 2009. № 7. С. 76-86.

17. Квіт С. Основи герменевтики: Текст лекцій. К. б.в. 1999. 124 с.

18. Клочек Г. Проблема Григорія Грабовича: момент істини. Дзеркало тижня. 2003. 1 листопада.

19. Костенко Л. Гуманітарна аура нації, або Дефект головного дзеркала. К. Видавничий дім «КМ Academia». 1999. 32 с.

20. Левчук Л. Західноєвропейська естетика XX століття. Навчальний посібник. К. Либідь. 1997. 224 с.

21. Моренець В. Голос у пустелі. Слово і час. 2006. № 4. С. 80-83.

22. Мороз Л. Триєдиність як основа універсалізму (національне загальнолюдське - духове). Нова історія украӥнської літератури (теоретико-методологічні аспекти). Зб. К. Фенікс. 2005. С. 86-101.

23. Наєнко М.К. Історія українського літературознавства i критики. навч. посіб. К. ВЦ «Академія». 2010. 520 с.

24. Павличко С. Методологічна ситуація в сучасному українському літературознавстві. Павличко С. Теорія літератури. Передм. Марії Зубрицької. К. Вид-во Соломії Павличко «Основи». 2002. C. 483-491.

25. Панченко В. Генітальна література, або Дурдом Софії Андрухович. Режим доступу: http://litakcent.com/2008/01/10/ volodymyr-panchenko-henitalna-literatura-abo-durdom-sofijiandruhovych/

26. Розумний М.M. Доктрина дії: Соціально-філософський конспект. Х. Майдан. 2009. 136 с.

27. Салига Т. Конфлікт світоглядів і поколінь чи наша «культурна війна»? Іванишин П. Агон, або Перипетії одного захисту: монографія. Дрогобич. Посвіт. 2015. С. 5-12. 
28. Сеник Л. Роман опору. Український роман 20-х років: проблема національної ідентичності. Львів. Академічний експрес. 2002. $239 \mathrm{c}$.

29. Сивокінь Г.М. У вимірах сприймання. Теоретичні проблеми художньої літератури, іiї історії та функцій. К. Фенікс. 2006. 304 с.

30. Скупейко Л., Дончик В. «Слово і час»: сторінки українського літературознавства. Слово і час. 2002. №8. С. 8-10.

31. Слемон С., Тіффін Г. Постколоніальна критика. Антологія світової літературно-критичної думки XX cm. За ред. М.Зубрицької. Львів. Літопис. 1996. С. 536-539.

32. Татаркевич В. Історія шести понять: Мистецтво. Прекрасне. Форма. Творчість. Відтворництво. Естетичне переживання. Пер. 3 пол. В.Корнієнка. К. Юніверс. 2001. 368 с.

33. Фаулз Дж. Арістос. Вінниця. Тезис. 2003. 340 с.

34. Фізер І. Зустрічі чи зіткнення української філології із західними методологічними стратегіями. Слово $i$ час. 2006. № 4. C. 5-10.

35. Фізер I.M. Американське літературознавство. Іст.-критич. Нарис. К. Вид. дім «Києво-Могилянська академія». 2006. 108 с.

36. Хоменко О. Любитипо-гарвардськи: типологія процесу. Хоменко О. Есеї республіканської осени. Тернопіль. Джура. 2011. C. $100-105$.

37. Хороб С.I. На літературних теренах. Дослідження, статті, рецензії. Івано-Франківськ. ПНУ ім. В.Стефаника. 2006. 410 с.

\section{Information about the author:} Ivanyshyn P. V.,

Doctor of Philology, Professor, Head of the Department of Ukrainian Literature and Theory of Literature,

Drohobych State Pedagogical University named after Ivan Franko 24, Shevchenko str., Drohobych, 82100, Ukraine 